Bull. Chem. Soc. Ethiop. 2016, 30(1), 71-78.

Printed in Ethiopia

ISSN 1011-3924

DOI: http://dx.doi.org/10.4314/bcse.v30i1.6

(C) 2016 Chemical Society of Ethiopia

\title{
SPECIATION OF BINARY COMPLEXES OF Pb(II) AND Cd(II) WITH L- ASPARAGINE IN DIMETHYL SULFOXIDE - WATER MIXTURES
}

\author{
Choppa Nageswara Rao ${ }^{1}$, Malla Ramanaiah ${ }^{1,2}$ and B.B.V. Sailaja ${ }^{1 *}$ \\ ${ }^{1}$ Department of Inorganic \& Analytical Chemistry, Andhra University, Visakhapatnam-530 003, \\ India \\ ${ }^{2}$ Department of Chemistry, Aditya Institute of technology and management, Tekkali-532201, \\ India
}

(Received November 3, 2014; revised September 16, 2015)

\begin{abstract}
Chemical speciation of L-Asparagine complexes of $\mathrm{Pb}$ (II) and $\mathrm{Cd}(\mathrm{II})$ in presence of $(0-50 \% \mathrm{v} / \mathrm{v})$ dimethyl sulfoxide(DMSO)-water mixtures has been studied potentiometrically at $303.0 \mathrm{~K}$ and at an ionic strength of $0.16 \mathrm{~mol} \mathrm{~L}^{-1}$. The models containing different number of species were refined by using the computer program MINIQUAD75. The number of species in the models is chosen based on exhaustive modeling. The predominant species formed are of the type $\mathrm{ML}_{2}, \mathrm{ML}_{2} \mathrm{H}$, and $\mathrm{ML}_{2} \mathrm{H}_{2}$. The best fit chemical models were chosen based on statistical parameters. The convenience of the models is ascertained by studying the effect of errors in concentrations of ingredients. The trend in variation of stability constants with change in the composition of medium is explained on the basis of predominant electrostatic and non-electrostatic forces. Chemical speciation was discussed based on the distribution diagrams.
\end{abstract}

KEY WORDS: Chemical speciation, L-Asparagine, Dimethyl sulfoxide, Stability constants

\section{INTRODUCTION}

In biological fluids, the metal ions exist in non-exchangeable form as metalloproteins or loosely bound to some biological ligands like metal-activated proteins. The loosely bound metal ions are in equilibrium with similar metal ions present in the bio-fluids. These simultaneous equilibria involving a variety of metal ions and ligands are important in biological fluids [1]. Hence, the chemical speciation of ligands with metal ions becomes of paramount importance in our laboratory [2-6].

L-Asparagine is one of the 20 most common natural amino acids on earth. It has carboxamide as the side-chain's group. It participates in the function of the brain and nervous system. It is required by the nervous system to maintain equilibrium and is also required for amino acid transformation from one form to the other in the liver.

Due to its numerous uses and high persistence, lead is a major environmental contaminant [7]. Lead is a major environmental contaminant [7] due to its various uses and its toxicity even at low concentration [8]. Lead intake by humans can be due to the consumption of crop plants grown on soils with high plant-available metal concentrations [9]. It can, however, migrate through the soil with dissolved organic matter [10] or mobilized by certain plants [11]. Moreover, it is carried from the air to the soil as fine particles and released more easily in soil solution [12].

Cadmium causes iron deficiency by binding to cysteine, glutamate, aspartate, and histidine ligands [13]. Cadmium inhibits enzymes that participate in bilirubine conjunction [14]. It increases urine $\mathrm{Ca}^{2+}$ excretion which can cause severe bone pathology [15]. The possible effects of long term low-level exposure to cadmium are of concern because it is readily distributed to tissues of liver and kidney, which are the main target organs in acute and chronic cadmium exposure $[16,17]$. Other tissues involved in cadmium toxicity include the testis, heart, bone,

*Corresponding author. E-mail: sailaja_bbv@yahoo.co.in 
eye, and brain [18]. Therefore, with this in mind, this work investigates speciation of binary complexes of $\mathrm{Pb}(\mathrm{II})$ and $\mathrm{Cd}(\mathrm{II})$ with L-Asparagine.

\section{EXPERIMENTAL}

\section{Materials}

L-Asparagine ( $\geqslant 99 \%$, Qualigens, India) solution $\left(0.05 \mathrm{~mol} \mathrm{~L}^{-1}\right)$ was prepared in triple-distilled water by maintaining $0.05 \mathrm{~mol} \mathrm{~L}^{-1}$ nitric acid concentration to increase the solubility. DMSO $\left(\left(\geqslant 99 \%\right.\right.$, Merck, India) was used as received without further purification. 2 mol L ${ }^{-1}$ sodium nitrate $((\geqslant 99 \%$, Qualigens, India) was used as supporting electrolyte to keep the ionic strength constant. $0.05 \mathrm{~mol} \mathrm{~L}^{-1}$ aqueous solutions of $\mathrm{Pb}(\mathrm{II})$ and $\mathrm{Cd}(\mathrm{II})$ nitrates were prepared by dissolving G.R. Grade ( $\geqslant 99 \%$, E-Merck, Germany) salts in triple-distilled water maintaining $0.05 \mathrm{~mol} \mathrm{~L}^{-1}$ nitric acid to suppress the hydrolysis of metal salts. All the solutions were standardized by standard methods. To assess errors in concentration determinations, the data were subjected to analysis of variance of one way classification [19]. The strengths of alkali and mineral acid were determined using the Gran plot method [20, 21].

\section{Instrumentation}

The titrimetric data were obtained using an ELICO (Model LI-120) pH meter (readability 0.01), which was calibrated with $0.05 \mathrm{~mol} \mathrm{~L}^{-1}$ potassium hydrogen phthalate in acidic region and 0.01 mol L $\mathrm{L}^{-1}$ borax solution in basic region. The glass electrode was equilibrated in a well stirred DMSO-water mixture containing the inert electrolyte. All the titrations were carried out in the medium containing varying concentrations of DMSO-water mixtures $(0-50 \% \mathrm{v} / \mathrm{v})$ at $303.0 \pm 0.1$ $\mathrm{K}$ and constant ionic strength of $0.16 \mathrm{~mol} \mathrm{~L}^{-1}$. The effect of variation in asymmetry potential, liquid junction potential, activity coefficient, sodium ion error, and dissolved carbon dioxide on the response of the glass electrode was accounted for by a correction factor [22, 23].

\section{Analytical procedures}

For the determination of stability constants of metal-ligand binary species, initially titrations of strong acid with alkali were carried out at regular intervals to check whether complete equilibration was achieved. Then the calomel electrode was refilled with acetonitrile-water mixture of equivalent composition as that of the titrand. In each of the titrations, the titrand composed of approximately $1 \mathrm{mmol}$ mineral acid in a total volume of $50 \mathrm{~mL}$. Titrations with different ratios 1:7.5, 1:8.5 and 1:10.0 in the case of $\mathrm{Cd}(\mathrm{II})$ and $\mathrm{Pb}(\mathrm{II})$ of metal-to-ligand were carried out with $0.4 \mathrm{~mol} \mathrm{~L}^{-1}$ sodium hydroxide. Other experimental details are as reported previously [24].

\section{Modeling strategy}

The computer program SCPHD [25] was used to calculate the correction factor. The binary stability constants were calculated with the $\mathrm{pH}$-metric titration data using the computer program MINIQUAD75 [26, 27], which exploits the advantage of a constrained least-squares method in the initial refinement and reliable convergence of the Marquardt algorithm. During the refinement of the binary systems, the correction factor and the protonation constants of Lasparagine were fixed. The variation of overall stability constants with the dielectric constant of the medium was investigated on electrostatic and non-electrostatic forces on the basis of solutesolute and solute-solvent interactions. 


\section{RESULTS AND DISCUSSION}

The results of the 'best fit' models that reveal the stoichiometry of the complex species and their overall formation constants along with some of the associated important statistical parameters are given in Table 1 . A very low standard deviation in $\log \beta$ values indicates the precision of these parameters. The small values of $U_{\text {corr }}$ (the sum of squares of deviations in concentrations of components at all experimental points) corrected for degrees of freedom, indicate that the model can represent the experimental data. Small values of mean, standard deviation and mean deviation for the systems corroborate that the residuals are around a zero mean with little dispersion. Kurtosis is a measure of the peakedness of the error distribution near a model value. For an ideal normal distribution kurtosis value should be three (mesokurtic) $[28,29]$. If the kurtosis is less than three, the peak of the error distribution curve is flat (platykurtic) and if the kurtosis is greater than three, the distribution shall have sharp peak (leptokurtic).

Table 1. Parameters of 'best fit' chemical models of M(II)-L-Asparagine complexes in DMSO-water mixtures.

\begin{tabular}{|c|c|c|c|c|c|c|c|c|c|c|}
\hline \multirow{2}{*}{$\begin{array}{c}\% \mathrm{v} / \mathrm{v} \\
\text { DMSO } \\
\end{array}$} & \multicolumn{3}{|c|}{$\log \beta_{\operatorname{mlh}}(\mathrm{SD})$} & \multirow[t]{2}{*}{ NP } & \multirow[t]{2}{*}{$\mathrm{U}_{\text {corr }}$} & \multirow[t]{2}{*}{ Skewness } & \multirow[t]{2}{*}{$\chi^{2}$} & \multirow{2}{*}{$\begin{array}{c}\mathrm{R}- \\
\text { Factor }\end{array}$} & \multirow[t]{2}{*}{ Kurtosis } & \multirow{2}{*}{$\begin{array}{c}\mathrm{pH} \\
\text { Range }\end{array}$} \\
\hline & $\mathrm{ML}_{2}$ & $\mathrm{ML}_{2} \mathrm{H}$ & $\mathrm{ML}_{2} \mathrm{H}_{2}$ & & & & & & & \\
\hline \multicolumn{11}{|c|}{$\mathrm{Pb}(\mathrm{II})$} \\
\hline 0 & $9.56(31)$ & $15.90(60)$ & $22.41(06)$ & 62 & 2.55 & -0.07 & 23.55 & 0.0097 & 3.29 & $2.0-6.5$ \\
\hline 10 & $9.62(33)$ & $16.60(38)$ & $22.71(46)$ & 15 & 1.57 & 0.02 & 3.89 & 0.0118 & 2.86 & $3.1-7.0$ \\
\hline 20 & $9.76(24)$ & 17.17(19) & $23.26(07)$ & 69 & 5.18 & 0.07 & 44.17 & 0.0135 & 4.68 & $2.0-7.0$ \\
\hline 30 & $9.90(68)$ & 17.21(36) & $23.12(13)$ & 65 & 20.91 & 0.18 & 44.88 & 0.0272 & 2.67 & $2.0-7.0$ \\
\hline 40 & $10.52(28)$ & $17.62(23)$ & $22.22(11)$ & 76 & 8.87 & -1.06 & 63.86 & 0.0177 & 5.31 & $2.0-8.0$ \\
\hline 50 & $10.32(31)$ & 17.74(31) & $23.55(33)$ & 28 & 4.94 & 0.28 & 9.14 & 0.0210 & 3.52 & $3.0-9.0$ \\
\hline \multicolumn{11}{|c|}{$\mathrm{Cd}(\mathrm{II})$} \\
\hline 0 & $8.33(14)$ & $16.35(16)$ & $23.37(09)$ & 75 & 4.82 & 0.14 & 16.10 & 0.0153 & 3.93 & $2.0-9.0$ \\
\hline 10 & $9.05(15)$ & $16.35(23)$ & $23.23(08)$ & 71 & 7.52 & -0.23 & 16.75 & 0.0173 & 3.87 & $2.0-8.0$ \\
\hline 20 & $9.79(31)$ & $16.32(48)$ & $21.25(42)$ & 90 & 7.05 & 0.72 & 97.53 & 0.0460 & 4.16 & $2.0-7.5$ \\
\hline 30 & $9.06(14)$ & $16.59(15)$ & $23.05(06)$ & 71 & 4.63 & -0.88 & 25.46 & 0.0134 & 7.23 & $2.0-8.0$ \\
\hline 40 & $9.11(17)$ & $16.43(20)$ & $22.72(08)$ & 73 & 6.93 & -0.41 & 30.61 & 0.0164 & 4.20 & $2.0-8.0$ \\
\hline 50 & $9.29(31)$ & $16.73(34)$ & $23.28(16)$ & 68 & 24.04 & -0.11 & 26.43 & 0.0321 & 3.44 & $2.0-8.0$ \\
\hline
\end{tabular}

$\mathrm{U}_{\text {corr }}=\mathrm{U} /(\mathrm{NP}-\mathrm{m}) \times 10^{8}$, where $\mathrm{m}=$ number of species; $\mathrm{NP}=$ number of experimental points; $\mathrm{SD}=$ standard deviation.

The kurtosis values in the present study indicate that the residuals form leptokurtic as well as platykurtic patterns and very few form mesokurtic patterns. The values of skewness recorded in Table are between -1.06 and 0.28 . These data suggest that the residuals form a part of normal distribution. Hence, least-squares method can be applied to the present data. The sufficiency of the model is further evident from the low crystallographic R-values. These statistical parameters thus show that the best fit models portray the metal - ligand species in DMSO media.

Effect of systematic errors on 'best fit' model

In order to obtain the best chemical model for critical evaluation and application under varied experimental conditions with different accuracies of data acquisition, an investigation was undertaken by introducing pessimistic errors in the influential parameters like concentrations of alkali, mineral acid, ligand and metal (Table 2). The order of the components that influence the magnitudes of stability constants due to incorporation of errors is alkali $>$ acid $>$ ligand $>$ metal. Some species were even rejected when errors are introduced in the concentrations. The rejection of some species and increased standard deviations in the stability constants on introduction of 
errors confirm the suitability of the experimental conditions (concentrations of components) and choice of the best fit models.

Table 2. Effect of errors in influential parameters on the stability constants of $\mathrm{Cd}(\mathrm{II})$-asparagine complexes in $40 \% \mathrm{v} / \mathrm{v}$ DMSO-water mixture.

\begin{tabular}{|c|c|c|c|c|}
\hline \multirow{3}{*}{ Reactant } & & \multicolumn{3}{|c|}{$\log \beta(\mathrm{SD})$} \\
\hline \multirow{4}{*}{ Alkali } & \% Error & $\mathrm{ML}$ & $\mathrm{ML}_{2} \mathrm{H}$ & $\mathrm{ML}_{2} \mathrm{H}_{2}$ \\
\cline { 2 - 5 } & 0 & $9.11(17)$ & $16.43(20)$ & $22.72(08)$ \\
\cline { 2 - 5 } & -5 & $13.47(20)$ & $20.26(13)$ & $24.11(10)$ \\
\cline { 2 - 5 } & -2 & $10.11(20)$ & $17.23(28)$ & $23.28(08)$ \\
\cline { 2 - 5 } & +2 & $8.13(15)$ & $15.59(20)$ & $21.87(13)$ \\
\hline \multirow{4}{*}{ Acid } & +5 & $7.15(13)$ & $14.64(27)$ & Rejected \\
\cline { 2 - 5 } & -5 & $6.46(21)$ & $14.07(54)$ & Rejected \\
\cline { 2 - 5 } & -2 & $7.76(17)$ & $15.33(23)$ & $21.65(19)$ \\
\cline { 2 - 5 } & +2 & $11.62(25)$ & $18.71(20)$ & $23.26(07)$ \\
\hline \multirow{4}{*}{ Ligand } & +5 & $14.61(30)$ & $20.68(11)$ & $23.96(11)$ \\
\cline { 2 - 5 } & -5 & $9.33(17)$ & $16.68(20)$ & $23.02(08)$ \\
\cline { 2 - 5 } & -2 & $9.03(16)$ & $16.33(20)$ & $22.58(08)$ \\
\cline { 2 - 5 } & +2 & $9.20(17)$ & $16.54(20)$ & $22.85(08)$ \\
\hline \multirow{4}{*}{ Metal } & +5 & $8.91(15)$ & $16.18(20)$ & $22.34(09)$ \\
\cline { 2 - 5 } & -5 & $9.30(18)$ & $16.49(22)$ & $22.79(08)$ \\
\cline { 2 - 5 } & -2 & $9.00(16)$ & $16.40(19)$ & $22.67(08)$ \\
\cline { 2 - 5 } & +2 & $9.05(17)$ & $16.41(20)$ & $22.69(08)$ \\
\hline
\end{tabular}

Effect of solvent

The dielectric constant is one of the characteristics of liquid. The proton-ligand and metal-ligand stability constants are strongly affected by the dielectric constant of the medium because of the fact that at least one of the constituents is charged and other is either changed or has a dipole. Variations in the relative strengths of acids and bases with changing solvents should be a function of the charge, the radius of the ion and the dielectric constants of the medium. When the ionization of an acid gives a net increase of ions, a decrease in the dielectric constant of the solvent should be accompanied by an increase in the protonation constant of a weak acid dissolved in it.
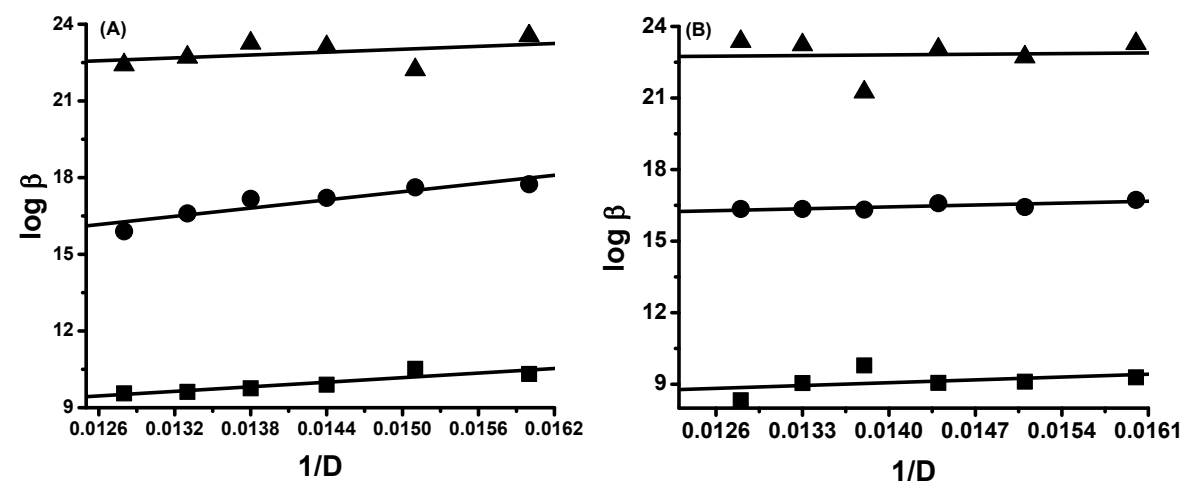

Figure 1. Variation of overall stability constant values of metal-L-asparagine complexes with DMSO-water mixtures (A) $\mathrm{Pb}(\mathrm{II})$ and (B) Cd(II);(•) $\log \beta_{\mathrm{ML} 2} ;(\bullet) \log \beta_{\mathrm{ML} 2 \mathrm{H}} ;(\mathbf{\Lambda}) \log \beta_{\mathrm{ML} 2 \mathrm{H} 2}$. 
The variation of overall stability constant values or change in free energy with co-solvent content depends upon two factors, viz., electrostatic and non-electrostatic forces. Born's classical treatment holds good in accounting for the electrostatic contribution to the free energy change [30]. According to this treatment, the energy of electrostatic interaction is related to dielectric constant. Hence, the logarithm of overall stability constant $(\log \beta)$ should vary linearly as a function of the reciprocal of the dielectric constant (1/D) of the solvent present. This is observed in the present study (Figure 1) this plot (Figure 1) in DMSO-water mixtures show that the $\log \beta$ values are linearly increasing with decreasing dielectric constant values of solvent.

\section{Distribution diagrams}

L-Asparaine is a bidentate ligand that has one dissociable (carboxyl group) and one associable (amino) protons. The different forms of $\mathrm{L}$-asparagine are $\mathrm{LH}_{2}{ }^{+}, \mathrm{LH}$, and $\mathrm{L}^{-}$in the $\mathrm{pH}$ range 1.55.0, 1.5-11.0, and 5.0-11.0, respectively. Hence, the plausible binary metal-ligand complexes can be predicted from these data. The present investigation reveals the existence of $\mathrm{ML}_{2}, \mathrm{ML}_{2} \mathrm{H}$, $\mathrm{ML}_{2} \mathrm{H}_{2}$ for $\mathrm{Pb}(\mathrm{II})$ and $\mathrm{Cd}(\mathrm{II})$. The $\mathrm{ML}_{2}$ species is the predominant species (Figure 2) at higher $\mathrm{pH}$ and $\mathrm{ML}_{2} \mathrm{H}_{2}$ is the predominant species at lower $\mathrm{pH}$ among all the binary complexes. Low concentration of free metal ion (FM) indicates the strong complexing nature of asparagine. The formation of various binary complex species is shown in the following equilibria. Some typical distribution diagrams of DMSO-water media are shown in Figure 2. The species $\mathrm{ML}_{2} \mathrm{H}_{2}, \mathrm{ML}_{2} \mathrm{H}$, $\mathrm{ML}_{2}$ are formed in the $\mathrm{pH}$ range of 3.5-7.0. $\mathrm{ML}_{2} \mathrm{H}_{2}$ is formed at lower $\mathrm{pH}$. $\mathrm{ML}_{2} \mathrm{H}$ and $\mathrm{ML}_{2}$ formed with the increasing $\mathrm{pH}$. $\mathrm{ML}_{2} \mathrm{H}$ and $\mathrm{ML}_{2}$ species percentage successively increases with increasing $\mathrm{pH}$. Successive deprotonation of $\mathrm{ML}_{2} \mathrm{H}_{2}$ forms $\mathrm{ML}_{2} \mathrm{H}$ beyond a $\mathrm{pH} 7.0$ [Equilibria (4) and (5)]. $\mathrm{ML}_{2}$ formed at higher $\mathrm{pH}$ with high percentage [Equilibria ((10), 11), (12) and (22). The percentage of the $\mathrm{ML}_{2}$ species increases successively with increasing in $\mathrm{pH}$ up to 7.0. The concentration of $\mathrm{ML}_{2} \mathrm{H}_{2}$ species decreased, while the concentration of $\mathrm{ML}_{2} \mathrm{H}$ and $\mathrm{ML}_{2}$ increased in the $\mathrm{pH}$ range 5.0-7.0.

\begin{tabular}{|c|c|c|}
\hline $\mathrm{M}(\mathrm{II})+\mathrm{LH}_{2}^{+}$ & $\longrightarrow$ & $\mathrm{ML}^{+}+2 \mathrm{H}^{+}$ \\
\hline $\mathrm{M}(\mathrm{II})+2 \mathrm{LH}_{2}^{+}$ & 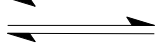 & $\mathrm{ML}_{2} \mathrm{H}_{2}{ }^{2+}+2 \mathrm{H}^{+}$ \\
\hline $\mathrm{MLH}^{2+}+\mathrm{LH}_{2}^{+}$ & $\Rightarrow$ & $\mathrm{ML}_{2} \mathrm{H}_{2}^{2+}+\mathrm{H}^{+}$ \\
\hline $\mathrm{ML}_{2} \mathrm{H}_{2}^{2+}$ & $\Longrightarrow$ & $\mathrm{ML}_{2} \mathrm{H}^{+}+\mathrm{H}^{+}$ \\
\hline $\mathrm{MLH}^{2+}+\mathrm{LH}$ & 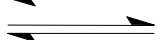 & $\mathrm{ML}_{2} \mathrm{H}^{+}+\mathrm{H}^{+}$ \\
\hline $\mathrm{M}(\mathrm{II})+\mathrm{LH}_{2}^{+}$ & $>$ & $\mathrm{MLH}^{2+}+\mathrm{H}^{+}$ \\
\hline $\mathrm{MLH}^{2+}$ & $\overline{7}$ & $\mathrm{ML}^{+}+\mathrm{H}^{+}$ \\
\hline $\mathrm{ML}^{+}+\mathrm{LH}_{2}^{+}$ & $\overline{7}$ & $\mathrm{ML}_{2} \mathrm{H}^{+}+\mathrm{H}^{+}$ \\
\hline $\mathrm{M}(\mathrm{II})+2 \mathrm{LH}_{2}^{+}$ & $\bar{\eta}$ & $\mathrm{ML}_{2} \mathrm{H}^{+}+3 \mathrm{H}^{+}$ \\
\hline $\mathrm{M}(\mathrm{II})+2 \mathrm{LH}_{2}^{+}$ & $=$ & $\mathrm{ML}_{2}+4 \mathrm{H}^{+}$ \\
\hline $\mathrm{ML}_{2} \mathrm{H}^{+}$ & $\overline{7}$ & $\mathrm{ML}_{2}+\mathrm{H}^{+}$ \\
\hline $\mathrm{ML}^{+}+\mathrm{LH}$ & $\overline{7}$ & $\mathrm{ML}_{2}+\mathrm{H}^{+}$ \\
\hline $\mathrm{ML}_{2} \mathrm{H}_{2}$ & $\overline{7}$ & $\mathrm{ML}_{2}^{2-}+2 \mathrm{H}^{+}$ \\
\hline $\mathrm{M}(\mathrm{II})+3 \mathrm{LH}_{2}^{+}$ & $\Longrightarrow$ & $\mathrm{ML}_{3} \mathrm{H}_{3}{ }^{2+}+3 \mathrm{H}^{+}$ \\
\hline $\mathrm{MLH}^{2+}+2 \mathrm{LH}_{2}^{+}$ & $\bar{\gamma}$ & $\mathrm{ML}_{3} \mathrm{H}_{3}{ }^{2+}+2 \mathrm{H}^{+}$ \\
\hline $\mathrm{ML}_{3} \mathrm{H}_{3}{ }^{2+}$ & $\overline{7}$ & $\mathrm{ML}_{3} \mathrm{H}_{2}^{+}+\mathrm{H}^{+}$ \\
\hline $\mathrm{ML}^{+}+2 \mathrm{LH}_{2}^{+}$ & $\bar{V}$ & $\mathrm{ML}_{3} \mathrm{H}_{2}^{+}+2 \mathrm{H}^{+}$ \\
\hline $\mathrm{ML}_{3} \mathrm{H}_{2}^{+}$ & $\overline{7}$ & $\mathrm{ML}_{3} \mathrm{H}^{-}+\mathrm{H}^{+}$ \\
\hline $\mathrm{ML}_{3} \mathrm{H}^{-}$ & $\nabla$ & $\mathrm{ML}_{3}^{2-}+\mathrm{H}^{+}$ \\
\hline $\mathrm{M}(\mathrm{II})+3 \mathrm{LH}_{2}^{+}$ & 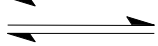 & $\mathrm{ML}_{3} \mathrm{H}_{2}^{+}+4 \mathrm{H}^{+}$ \\
\hline $\mathrm{M}(\mathrm{II})+3 \mathrm{LH}_{2}^{+}$ & $\nabla$ & $\mathrm{ML}_{3} \mathrm{H}+5 \mathrm{H}^{+}$ \\
\hline $\mathrm{M}(\mathrm{II})+3 \mathrm{LH}_{2}^{+}$ & 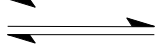 & $\mathrm{ML}_{3}^{-}+6 \mathrm{H}^{+}$ \\
\hline
\end{tabular}




$$
\begin{array}{lll}
\mathrm{ML}_{2}+\mathrm{LH} & = & \mathrm{ML}_{3}^{-}+\mathrm{H}^{+} \\
\mathrm{ML}_{3} \mathrm{H}_{3} & = & \mathrm{ML}_{3} \mathrm{H}^{2-}+2 \mathrm{H}^{+} \\
\mathrm{ML}_{3} \mathrm{H}_{3} & = & \mathrm{ML}_{3}^{3-}+3 \mathrm{H}^{+}
\end{array}
$$
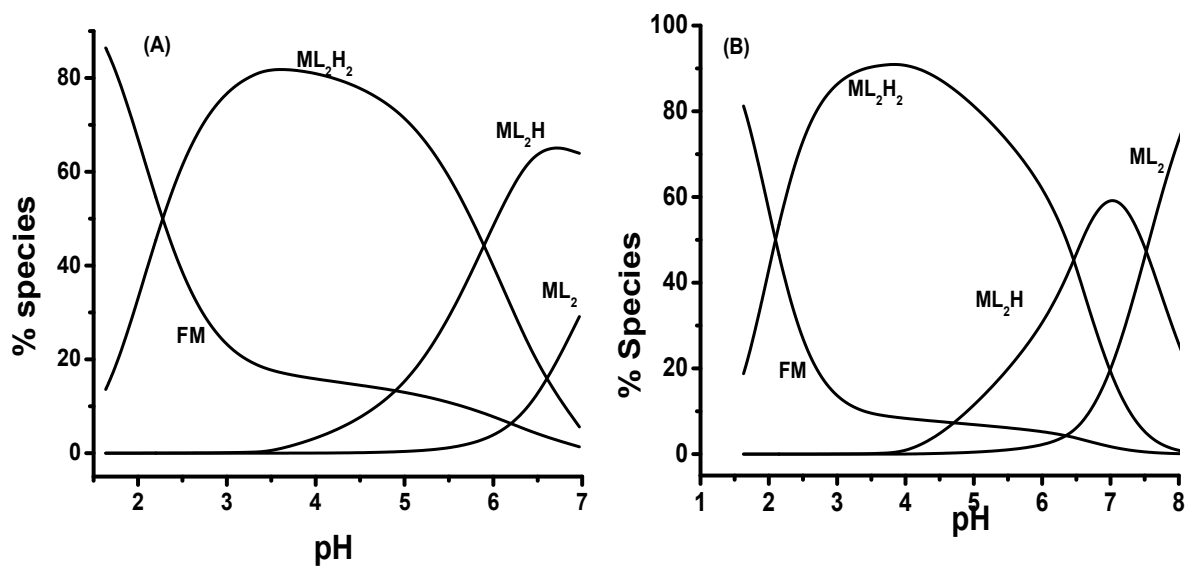

Figure 2. Distribution diagrams of L-asparagine complexes in 30\% v/v DMSO-water medium. (A) $\mathrm{Pb}$ (II) and (B) Cd (II).

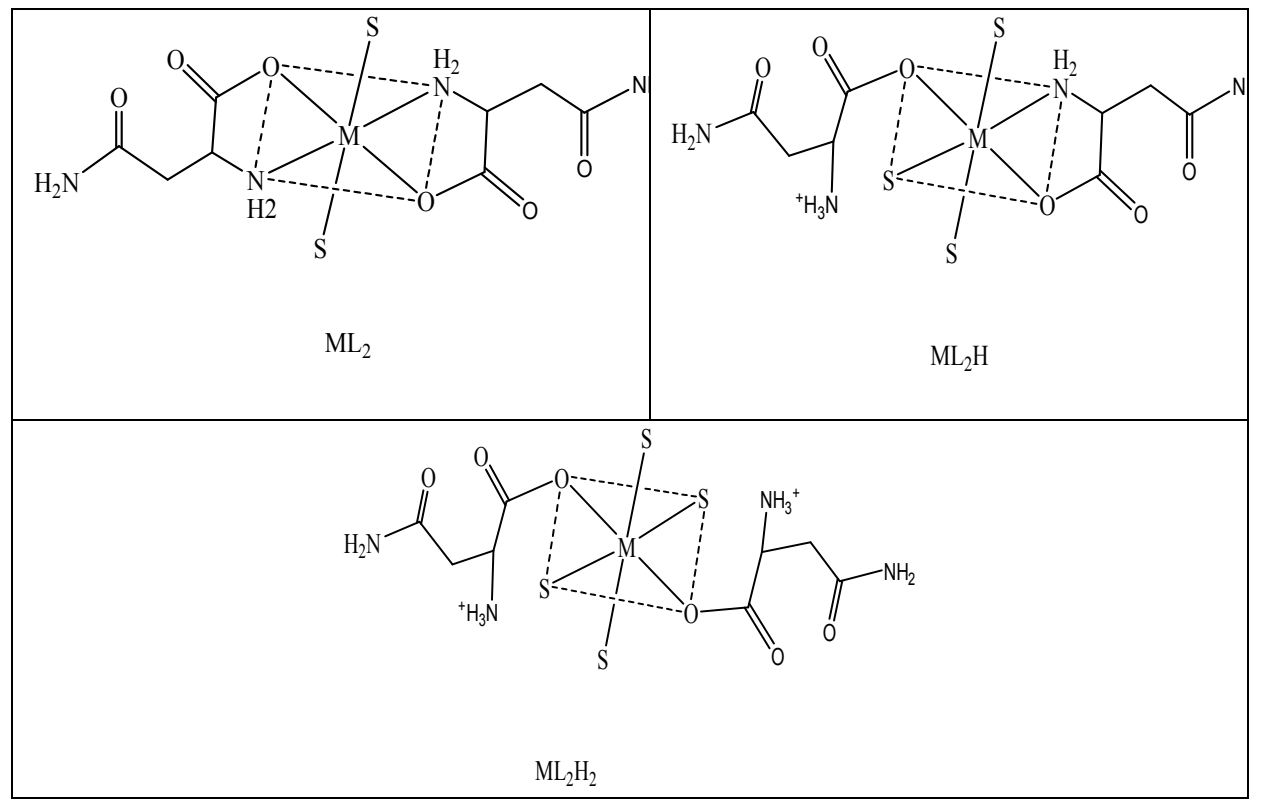

Figure 3. Structure of L-asparagine complexes ( $\mathrm{S}$ is either solvent or water molecules). 
Speciation of binary complexes of $\mathrm{Pb}(\mathrm{II})$ and $\mathrm{Cd}(\mathrm{II})$ with L-asparagine in DMSO- $\mathrm{H}_{2} \mathrm{O}$ mixture 77

\section{CONCLUSIONS}

The binary species detected are $\mathrm{PbL}_{2}, \mathrm{PbL}_{2} \mathrm{H} \mathrm{PbL}_{2} \mathrm{H}_{2}, \mathrm{CdL}_{2}, \mathrm{CdL}_{2} \mathrm{H}$ and $\mathrm{CdL}_{2} \mathrm{H}_{2}$. These models are validated by statistical treatment of data. The linear or almost linear variation of stability constants as a function of mole fraction of the medium indicates the dominance of electrostatic forces over non-electrostatic forces. The linear variation of overall stability constants with dielectric constants of the medium indicates the dominance of electrostatic forces over nonelectrostatic forces. Some species are stabilized due to electrostatic interactions and some are destabilized due to the decreased dielectric constant. The order of components is influencing the magnitudes of stability constants due to incorporation of errors in their concentrations is alkali $>$ acid $>$ ligand $>$ metal.

\section{REFERENCES}

1. May, P.M.; Linder P.W.; Williams, D.R. J. Chem. Soc. Dalton 1977, 44, 588.

2. Ramanaiah, M.; Goutham Sri, S.; Sailaja, B.B.V. Chem. Spec. Bioavail. 2013, 25, 285.

3. Ramanaiah, .M; Sailaja, B.B.V. J. Indian Chem. Soc. 2014, 91, 639.

4. Rama Raju, B.; Santhee Devi, K.V.; Rao, G.N. Bull. Chem. Soc. Ethiop. 2011, 25, 43.

5. Santhee Devi, K.V.; Rama Raju, B.; Rao, G.N. J. Indian Chem. Soc. 2011, 88, 567.

6. Santhee Devi, K.V.; Rama Raju, B.; Rao, G.N. Rao, J. Indian Chem. Soc. 2012, 89, 753.

7. Chen, Y.; Wang, C.; Wang, Z. Environ. Int. 2005, 31, 778.

8. Canfield Jr, R.L.; Henderson, C.R.; Cory-Slechta, D.A.; Cox, C.; Jusko, T.A.; Lanphear, B.P. New England J. Med. 2003, 348, 1517.

9. Alexander, P.D.; Alloway, B.J.; Dourado, A.M. Environ. Pollut. 2006, 144, 736.

10. Cecchi, M.; Dumat, C.; Alric, A.; Felix-Faure, B.; Pradere, P.; Guiresse, M. Geoderma 2008, 144, 287.

11. Arshad, M.; Silvestre, J.; Pinelli, E.; Kallerhoff, J.; Kaemmerer, M.; Tarigo, A.; Shahid, M.; Guiresse, M.; Pradere, P.; Dumat, C. Chemosphere 2008, 71, 2187.

12. Komarnicki, G.J.K. Environ. Pollut. 2005, 136, 47.

13. Castagnetto, J.M.; Hennessy, S.W.; Roberts, V.A.; Getzoff, E.D.; Tainer, J.A.; Pique, M. E. Nucleic Acids Res. 2002, 30, 379.

14. Zeneli, L.; Pac,arizi, H.; Daci, N.M.; Daci-Ajvazi, M.; Prenaj, A. Am. J. Biochem. Biotechnol. 2009, 5, 59.

15. Takebayashi, S.; Jimi, S.; Segawa, M.; Kiyoshi, Y. Pathology Res. Pract. 2000, 196, 653.

16. Chater, S.; Douki, T.; Favier, A.; Sakly, M.; Abdelmelek, H. Acta Biol. Hung. 2009, 60, 79.

17. Asagba S.O.; Obi, F.O. Trop. J. Environ. Sci. Health 2000, 3, 33.

18. Asagba, S.O. Nigerian J. Sci. Environ. 2007, 6, 91.

19. Rao, R.S.; Rao, G.N. Computer Applications in Chemistry, Himalaya Publishing House, Mumbai: India; 2005; p 302.

20. Gran, G. Analyst 1952, 77, 661.

21. Gran, G. Anal. Chim. Acta 1988, 206, 111.

22. Ramanaiah, M.; Goutham Sri, S.; Sailaja, B.B.V. Bull. Chem. Soc. Ethiop. 2014, 28, 383.

23. Ramanaiah, M.; Nageswara Rao, C.H.; Sailaja, B.B.V. Proc. Nat. Acad. Sci. India 2014, 84, 485.

24. Rama Raju, B.; Santhee Devi, K.V.; Rao, G.N. Chinese J. Inorg. Chem. 2012, 28, 785.

25. Ramanaiah, M.; Goutham Sri, S.; Sailaja, B.B.V. J. Indian Chem. Soc. 2014, 91, 351.

26. Gans, P; Sabatini, A; Vacca, A. Inorg. Chim. Acta 1976, 18, 237.

27. Rao, R.S.; Rao, G.N. Computer Applications in Chemistry, Himalaya Publishing House: Mumbai; 2005; p 277.

28. Ramanaiah, M.; Sailaja, B.B.V. Chem. Spec. Bioavail. 2014, 26, 119.

29. Ramanaiah, M.; Sailaja, B.B.V. J. Appl. Chem. 2014, 3, 1118.

30. Ramanaiah, M.; Goutham Sri, S.; Sailaja, B.B.V. Chem. Speciat. Bioavail. 2014, 26, 231.

Bull. Chem. Soc. Ethiop. 2016, 30(1) 
31. Nageswara Rao, C.H.; Ramanaiah, M.; Sailaja, B.B.V. Chem. Speciat. Bioavail. 2014, 26, 266.

32. Born, M. Z. Phys. 1920, 1, 45. 